\title{
Restructuring to Repair Legitimacy - A Contingency Perspective
}

\author{
Pengii Wang*
}

\begin{abstract}
Manuscript Type: Empirical

Research Question/Issue: This study examines the effectiveness of restructuring in repairing legitimacy after a firm is punished for financial fraud.

Research Findings/Insights: We use the antecedents of fraud to distinguish between three types of financial fraud and argue that different types of such fraud affect different dimensions of legitimacy. We also identify four types of restructuring and adopt a contingency perspective to argue that the type of restructuring adopted should match the dimensions of legitimacy affected for a successful legitimacy repair, which is proxied by a positive market response when the restructuring is announced. Using a sample of Chinese listed firms, we find that disassociation from illegitimate business operations and creation of valuable business operations are more effective in repairing legitimacy after fraudulent financial reporting. Disassociation from illegitimate organizational structures and creation of monitors are more effective following embezzlement or stock market manipulation. However, no type of restructuring is effective following improper accounting practice. Market investors value creation of monitors more than they do disassociation from an illegitimate organizational structure, and attach the same value to disassociation from illegitimate business operations and creation of valuable business operations.

Theoretical/Academic Implications: This study makes three contributions to the organizational legitimacy and corporate crisis management literature. First, it links corporate crises arising from financial fraud to social legitimacy. Second, it extends the number of restructuring types identified in the legitimacy literature to four, taking content and form as two dimensions. Third, it links corporate crises arising from financial fraud to the effectiveness of responsive restructurings via social legitimacy.

Practitioner/Policy Implications: Firms punished for financial fraud should signal restructuring according to the nature of the fraud and address the pertinent dimensions of legitimacy.
\end{abstract}

Keywords: Corporate Governance, Financial Fraud, Social Legitimacy, Restructuring

\section{INTRODUCTION}

$\mathbf{O}$ rganizational crisis management is an important topic because an organizational crisis will negatively affect the legitimacy of the organization, which may further threaten the organization's survival in the worst-case scenario. In this sense, organizational crisis management is simply the procedure by which the firm seeks to repair organizational legitimacy. Although the last several decades have seen a productive stream of research on crisis management (e.g., Agrawal, Jaffe, \& Karpoff, 1999; Elsbach \& Sutton, 1992; Livingston, 1997; Schlenker, 1980; Staw, Mckechnie, \&

*Address for correspondence: Department of Business Policy, National University of Singapore, 17 Law Link, Singapore 117591. Tel: (65) 9787 5876; E-mail: pengji.wang@ nus.edu.sg
Puffer, 1983; Tedeschi, 1981), organizational crises have only recently been examined from a social interaction perspective (Breitsohl, 2009). Moreover, while image restoration strategies have been incorporated into explanations of effective crisis management, it remains unclear why some reactions are useful in overcoming a certain type of crisis, while others are not.

This study seeks to understand organizational crisis management from a social interactive perspective by linking organizational crises with the effectiveness of response strategies via social legitimacy. Specifically, we focus on the punishment of corporate financial fraud, a typical organizational crisis that threatens the social legitimacy of the organization. According to Zahra, Priem, and Rasheed (2005), corporate financial fraud refers to deliberate action taken by management at any level to deceive, con, swindle, or cheat investors 
or other key stakeholders. When the fraud is publicly revealed and punished, the firm will be penalized not only through litigation, but also via a loss of social legitimacy. For example, it will lose support from market investors, who will no longer have confidence in the firm's performance and credibility (Karpoff \& Lott, 1993). These effects will lead to negative market response (Karpoff \& Lott, 1993), which is an indicator of a legitimacy crisis. The firm must take steps to repair its legitimacy to regain support from market investors.

Prior literature on legitimacy suggests that to repair its legitimacy, the firm can either normalize its accounts or initiate a restructuring (Suchman, 1995). The account normalization strategy is addressed in the impression management literature, which stresses the importance of communication following a crisis. Communication is effective when the fraud is disclosed through the "bamboo telegraph" rather than being publicly revealed (Schlenker, 1980; Tedeschi, 1981). When the fraud is publicly revealed, the firm is better advised to take substantive measures to signal the effort it is making to reduce the likelihood of fraud occurring in future.

Suchman (1995) identifies two types of restructuring strategies aimed at repairing legitimacy: creating a monitoring mechanism and disassociation from key individuals, processes, structures, etc. Later studies follow Suchman (1995) and examine whether firms implement more leadership changes or improve their monitoring systems after revelations of fraud. However, empirical results are not entirely consistent with the finding that firms predominantly adopt monitoring and disassociation strategies: some empirical studies have lent support to such a prediction (Farber, 2005; Gerety \& Lehn, 1997; Livingston, 1997), while others have not (Agrawal et al., 1999; Fich \& Shivdasani, 2005).

These inconsistent results could be attributed to two reasons. First, prior studies may not have recognized that there are several distinct types of financial fraud, each of which may hurt different dimensions of legitimacy. For example, some financial frauds may hurt the firm's moral legitimacy, as a result of which the market will challenge the firm's intentions. Others may hurt the firm's pragmatic legitimacy, following which the market will lose confidence in the firm's ability to provide value. The response strategy adopted should match the distinct legitimacy dimension requiring attention for an optimal effect (Suchman, 1995). Second, the response strategies examined in prior studies are limited to organizational restructurings, which may be more effective for some types of fraud, but not for others. To repair legitimacy following other types of fraud, organizations may need to restructure other aspects of their operations.

This study seeks to fill the gaps in the literature identified above. Mainly drawing from literature on financial fraud and organizational legitimacy, we adopt a contingency perspective to examine the effectiveness of restructurings in repairing legitimacy after firms are punished for different types of financial fraud. We identify four dimensions of organizational legitimacy: regulative, pragmatic, moral, and cognitive legitimacy. We then argue that the detection of financial fraud may hurt different dimensions of organizational legitimacy, although all forms of financial fraud hurt regulative legitimacy. We examine the diverse range of antecedents of financial fraud: one of the antecedents of fraudu- lent financial reporting, which hurts the firm's pragmatic legitimacy, is performance pressure; one of the antecedents of embezzlement and stock market manipulation, which damages the organization's moral legitimacy, is insider interests; improper accounting practice, which hurts the regulative legitimacy of the firm, is not motivated by either performance pressure or insiders' intentions to seize benefits that properly belong to the firm or to other stakeholders. We also regard content and form as two dimensions in identifying four types of restructuring aimed at responding to a legitimacy crisis: disassociation from an illegitimate organizational structure, disassociation from illegitimate business operations, creation of monitors, and creation of valuable business operations. We argue that the type of restructuring implemented should match the dimension(s) of legitimacy requiring attention for a successful legitimacy repair, which is proxied by a positive market response when the restructuring is announced.

Taking Chinese listed firms punished for financial fraud (fraud firms) and matched nonfraud firms (nonfraud firms) as our sample, we first conduct an event study to compare the market response with restructuring announcements made by the fraud firms and the nonfraud firms. We then use ordinary least squares (OLS) regression models to examine whether and how the market response to a restructuring announcement depends on the nature of the financial fraud. Our results show that the four types of restructuring lead to a more positive market response for the fraud firms than for the nonfraud firms. Disassociation from illegitimate business operations and creation of valuable business operations are more effective restructuring strategies for firms punished for fraudulent financial reporting, which hurts firms' pragmatic legitimacy. Disassociation from illegitimate organizational structures and creation of monitors are more effective strategies for firms punished for embezzlement or stock market manipulation, both of which hurt firms' moral legitimacy. However, no form of restructuring is effective in repairing legitimacy following improper accounting practice. Market investors value creation of monitors more than they do disassociation from an illegitimate organizational structure, while they attach equal value to disassociation from illegitimate business operations and creation of valuable business operations.

\section{THEORETICAL BACKGROUND}

\section{Dimensions of Legitimacy Crises}

The extant literature posits several classifications of organizational legitimacy. For example, Scott (1995) proposes that there are three types of organizational legitimacy: regulative, normative, and cognitive. Regulative legitimacy is derived on the basis of compliance with legal or quasi-legal requirements in which the possibility of sanctions coerces organizations into adherence to rules. Normative legitimacy has a moral basis in that it mirrors perceived appropriateness in terms of norms, which govern what is important and how things should be done. Cognitive legitimacy reflects the extent to which an organization and its activities are culturally supported and conceptually correct, i.e., the degree to which a firm's actions are taken for granted. 
Suchman (1995) identifies three dimensions of organizational legitimacy: pragmatic, moral, and cognitive. Pragmatic legitimacy is based on stakeholders' self-interest calculations with respect to the expected value to be provided by the organization. Moral legitimacy reflects a positive normative evaluation of the organization and its activities and rests on judgments about whether a certain activity is "the right thing to do." Cognitive legitimacy is governed by shared definitions and frames of reference.

The normative legitimacy (Scott, 1995) and moral legitimacy (Suchman, 1995) constructs are conceptually equivalent. Scott and Suchmans' categorizations therefore suggest that there are four major dimensions of organizational legitimacy: pragmatic legitimacy, moral legitimacy, cognitive legitimacy, and regulative legitimacy. Among the four types of legitimacy, regulative legitimacy has a special status because it comes from actors who have sovereignty over organizations such as government agencies. The other three types of legitimacy flow from market investors. Because this study focuses on the effectiveness of repairing legitimacy derived from market investors, we do not consider regulative legitimacy in detail here.

\section{Response Strategies to Repair Legitimacy}

Discussion of restructuring strategies in prior legitimacy literature mainly focuses on two types. The first type of restructuring includes replacing illegitimate executives, structures, or procedures. It signals a parting from illegal influences and reorientation toward more morally appropriate and regular behavior (Scott, 1995; Suchman, 1995). We term this approach dissociation from an illegitimate organizational structure. The second type of restructuring is to establish a monitoring system by employing board directors, block shareholders, and other organizational structures (Suchman, 1995). Organizations use such monitoring systems to ensure they follow appropriate procedures and perform in a morally acceptable and rule-conforming manner. We term this type of restructuring the creation of monitors. Both types of restructuring signal that the organization should be considered an appropriate partner worthy of support.

The two forms of restructuring outlined above focus on organizational structure. However, corporate restructuring literature suggests that in addition to those that adjust the organizational structure, restructurings can also focus on reforming business operations including the firm's business portfolio and financial structure. A restructuring of business operations sends a message to the market that the organization is improving its operational efficiency and thus providing market investors with better utility. Business portfolio restructurings can be implemented in several ways including asset acquisitions whereby the firm purchases key assets from a target company and stock acquisitions in which the firm seeks to acquire control of a target company through a stock purchase or exchange. Both asset acquisitions and stock acquisitions can be viewed as value creation strategies in which the firm acquires valuable assets, projects, or product lines. We refer to such acquisitions as the creation of valuable business operations. Asset divestment refers to the sale of assets such as tangible fixed assets or intangible assets to other companies, while subsidiary divestment refers to the

\section{FIGURE 1 \\ Four Types of Restructuring}

\begin{tabular}{|c|c|c|}
\multicolumn{1}{c}{ Disassociation } & \multicolumn{1}{c}{ Organizational structure } & Business structure \\
\cline { 2 - 3 } Creation & Disassociation from illegitimate & Disassociation from illegitimate \\
organizational structure & business operations \\
(CEO dismissal) & (Asset divestment \\
& Subsidiary divestment \\
& Creation of monitors & Debt restructuring) \\
(Board chairman succession & Creation of valuable business \\
Ownership restructuring) & operations \\
& & (Asset acquisition \\
& & Stock acquisition) \\
\hline
\end{tabular}

sale of subsidiaries to other companies. Divestments can be viewed as a form of disassociation from unproductive or illegitimate business assets, projects, or product lines. Financial restructuring refers to a change in the firm's capital structure. Debt restructuring is one of the most important ways in which the firm's capital structure can be changed and refers to an increase or decrease in firm leverage. Examples of debt restructuring include interest forgiveness/deduction/ extension, the transfer of debt obligations, taking on new debt, and debt-for-equity swaps. Debt restructuring helps the firm to move away from an unhealthy capital structure. We refer to asset divestment, subsidiary divestment, and debt restructuring as disassociation from illegitimate business operations.

In summary, restructurings can be conducted on two types of contents (organizational structure and business operation) and in two distinct forms (disassociation and creation). Our conception of restructuring strategies based on the two dimensions of content and form therefore gives us four types of restructuring to respond to a legitimacy crisis: disassociation from an illegitimate organizational structure including the replacement of executives, organizational structures and procedures; disassociation from illegitimate business operations including asset divestment, subsidiary divestment, and debt restructuring; the creation of monitors, which refers to establishing a monitoring system incorporating board directors, block shareholders, and other organizational structures; and the creation of valuable business operations including asset acquisition and stock acquisition. These categories are shown in Figure 1.

\section{Contingency Perspective}

The contingency paradigm can be traced back to the work of Chandler (1962). According to this paradigm, the effectiveness of a strategy is contingent upon antecedent conditions (Meyer, Tsui, \& Hinings, 1993). In the context of this study, the contingency rationale suggests that a legitimacy repair strategy will be effective if the restructuring matches the dimensions of legitimacy affected by the crisis. We apply this framework to crises arising from the detection of financial fraud in the following section. 


\section{Theoretical Development}

Crises can occur in many forms. Marcus and Goodman (1991) distinguish between three types: accidents, product safety and health incidents, and scandals. This study focuses on crises arising from the detection of financial fraud, which can be viewed as a type of scandal, for two reasons. First, from a theoretical perspective, the detection of financial fraud could affect several dimensions of legitimacy including regulative legitimacy, pragmatic legitimacy, and moral legitimacy. It therefore provides us with an opportunity to examine the contingency effect. Second, in terms of deniability, while accidents are plausibly deniable because they occur unexpectedly and product safety and health incidents lie somewhere in the middle, scandals are difficult to deny because their causes are misdeeds within the organization. Organizations therefore need to accommodate crises arising from the detection of financial fraud and react in a more robust fashion, such as via a restructuring, to repair their legitimacy, which is the focus of this study. Third, although prior studies have examined the antecedents of financial fraud, few have examined the effectiveness of response strategies implemented in the wake of such malfeasance.

In this section, we develop two sets of hypotheses to examine the effectiveness of restructuring efforts made to repair legitimacy after firms are punished for financial fraud. In the first set of hypotheses, we examine the effectiveness of restructuring among fraud firms and nonfraud firms. In the second set of hypotheses, we examine whether the effectiveness of restructuring in repairing legitimacy depends on the type of fraud committed, taking social legitimacy as the latent construct.

According to Khurana and Lippincott (2000), when the purpose of the restructuring is unclear, market investors often fail to respond positively to the firm's restructuring proposal. Punishing a firm for financial fraud might challenge multiple dimensions of its legitimacy. The firm's moral legitimacy is called into question because of the morally reprehensible behavior with which it is now associated. In addition, given that financial fraud often arises because the firm is not well managed and thus misreports its financial performance, the firm's pragmatic legitimacy is hurt. In such a scenario, when a fraud firm announces a restructuring plan, it sends out a message that it is taking steps to repair its legitimacy by improving its operational performance or corporate governance. In this sense, restructurings implemented by fraud firms will give market investors a clearer picture of their purpose than those conducted by nonfraud firms. Restructuring announcements made by fraud firms will therefore be met with a more positive market response than those made by nonfraud firms. We therefore propose the following hypothesis:

Hypothesis 1. All types of restructuring lead to a more positive market response among fraud firms than they do among nonfraud firms.

We next consider the nature of the financial fraud committed and identify which legitimacy dimension is affected by each type of financial fraud. In terms of their consequences, all types of financial fraud hurt firms' regulative legitimacy because they are criminal offenses and are subject to regu- latory sanctions. However, because regulative legitimacy is not our focus, we do not discuss it in detail here.

In addition to considering the consequences of different forms of financial fraud, we also examine the motivations underlying the conduct of the parties involved and differentiate financial fraud into three types based on Clinard and Quinney's (1973) typology. These three types of financial fraud will hurt different dimensions of the firm's legitimacy.

Clinard and Quinney (1973) focus on the offense of financial fraud and differentiate corporate crimes from occupational crimes. Corporate crimes are those in which the firm benefits while others in society are the victims. They are motivated by performance pressure including the risk of financial distress (Maksimovic \& Titman, 1991), a lack of financial slack (Stein, 1989), and high-growth potential exceeding the firm's financial capabilities (Bebchuk \& BarGill, 2003; Wang, 2004). Fraudulent financial reporting is an important corporate crime. Some firms commit fraudulent financial reporting by misreporting their financial circumstances including earnings, revenue, and other aspects of financial health. Fraudulent financial reporting allows firms to avoid bankruptcy, raise external capital, and exercise their recovery or growth options on favorable terms at the expense of other stakeholders such as creditors and minority shareholders. The detection of fraudulent financial reporting will therefore lead market investors to believe that the firm is not well managed and that the utility is threatened, thus leading to a pragmatic legitimacy crisis.

Suchman (1995) explains that pragmatic legitimacy rests on individual utility calculations. Therefore, offering tangible rewards to stakeholders is more effective in gaining pragmatic legitimacy. To repair pragmatic legitimacy following the detection of fraudulent financial reporting, the firm needs to convince the market that it no longer faces performance pressure and no longer has an incentive to commit such fraud. This will lead market investors to assess the firm's utility at a higher level.

As the public assesses firms' payoffs from managers' choice of business strategies (Fombrun \& Shanley, 1990), firms can restructure their business operations to inform market investors about corporate managers' preoccupations and therefore signal the firm's future payoff prospects. Firms can signal their payoff prospects in two ways. On the one hand, they can disassociate the firm from illegitimate business operations. For example, divesting assets, spinning off business lines, or selling subsidiaries could imply that the firm is ridding itself of its inefficient sections and will perform better in the future (e.g., Comment \& Jarrell, 1995; Hoskisson \& Hitt, 1994; Markides, 1992). A debt restructuring signals that the firm is disposing of nonperforming capital and assets and thereby alleviating its liability pressure and lowering the risk of financial distress. On the other hand, firms can create valuable business operations. For example, asset acquisitions and stock acquisitions could indicate that the firm is in the process of expanding by pursuing promising projects or product lines (e.g., Hoskisson \& Hitt, 1990; Palmer, Barber, Zhou, \& Soysal, 1995). Both the disassociation from illegitimate business operations and the creation of valuable business operations can inform market investors of firms' strategic adjustments to their business portfolio and financial structure. This can help repair the 
firm's pragmatic legitimacy as reflected in a positive market response to the restructuring announcement. In contrast, because restructurings that center on organizational structure, i.e., disassociation from an illegitimate organizational structure and creation of monitors, cannot provide tangible rewards to market investors, they are not particularly effective in repairing pragmatic legitimacy. We therefore propose the following hypothesis:

Hypothesis 2a. For firms punished for fraudulent financial reporting, disassociation from illegitimate business operations and creation of valuable business operations have a stronger positive effect on the market response than do disassociation from an illegitimate organizational structure and creation of monitors.

Occupational crimes are those committed against a firm but for the benefit of insiders (Clinard \& Quinney, 1973). They are not motivated by performance considerations, but by the personal interests of a group of insiders (La Porta, Lopez-de-Silanes, \& Shleifer, 1999; Claessens, Djankov, Fan, \& Lang, 2002). Embezzlement and stock market manipulation are two types of occupational crime. Embezzlement refers to insiders (managers or block shareholders) stealing the funds or property of an employer, company, or government or misappropriating money or assets held in trust. Stock market manipulation refers to an attempt made by insider manipulators to influence the price of a stock by buying, selling, or hyping it. ${ }^{1}$ Insider manipulators can then profit from buying shares at a lower price and selling them at a higher price (Aggarwal \& Wu, 2003). In both types of fraud, a group of insiders, such as the firm's managers or controlling owners, are the sole beneficiaries and the firm and its other stakeholders are the victims. There is evidence that a weak internal control structure, including a firm's leadership, procedures and structure headed by the board of directors, the CEO, and the controlling shareholder(s), encourages and facilitates the occurrence of occupational crimes (Beasley, 1996; Beasley, Carcello, Hermanson, \& Lapides, 2000; Chen, Firth, Gao, \& Rui, 2005; Zahra et al., 2005). When embezzlement or stock market manipulation is detected in a firm, market investors will believe that the firm intends to act in a manner contrary to their interests and that their interests cannot be properly protected by the existing internal control structure. In this scenario, the firm's moral legitimacy is at issue.

Suchman (1995) explains that providing tangible rewards to the firm's managers may be regarded as unacceptable in moral terms because moral legitimacy requires a cultural framework. Market investors evaluate moral legitimacy in three ways: by examining outputs, by examining procedures and structures, and by examining individuals (Scott, 1977; Scott \& Meyer, 1991). Procedural and structural legitimacy, as well as individual legitimacy, become highly significant in the absence of clear outcome measures (Scott, 1992). In our research context, moral legitimacy, i.e., insiders' intentions, is not easy to observe or measure. To maintain the message that they seek to repair the organization's moral legitimacy, organizations often address procedure and structure, as well as individuals. The message can be sent in two ways. First, firm leaders are perceived to be able to transcend and reorder established routines. Firms thus can disassociate themselves from critical leaders who are perceived to be responsible for fraudulent behavior to dodge stigmatizing events (Agrawal et al., 1999). Second, prior studies on financial fraud suggest that the creation of a better corporate governance structure helps fraud firms to restore their reputation (Farber, 2005). For example, changing the chairman of the board can be a way of creating more effective board monitoring. Ownership restructuring involves a change in controlling rights such as a new main shareholder or an adjustment in the main shareholder's shareholding and is associated with a decrease in the controlling shareholder's power and a greater voice for other block shareholders. Ownership restructuring can be a way of creating more effective monitoring by block shareholders.

In summary, when embezzlement or stock market manipulation is detected in a firm, because the firm is not necessarily subject to performance pressure, a restructuring plan that addresses performance, i.e., disassociation from illegitimate business operations and creation of valuable business operations is likely to be ineffective. The firm should instead adopt a form of organizational restructuring that signals the firm's intention to disassociate itself from the individual(s) accused of illegitimate conduct or to create a better monitoring structure. Restructuring proposals of this kind are more effective in convincing the market that the firm's intentions are benign and that embezzlement or stock market manipulation is less likely in future.

Hypothesis 2b. For firms punished for embezzlement or stock market manipulation, disassociation from an illegitimate organizational structure and creation of monitors have a stronger positive effect on market response than do disassociation from illegitimate business operations and creation of valuable business operations.

A third type of fraud which falls outside Clinard and Quinney's (1973) typology is improper accounting practice. Improper accounting practice does not benefit the firm, its insiders, or others in society. It is motivated by neither performance pressure nor the self-interest of insiders, but is an unintentional form of misbehavior. It therefore hurts the firm's regulative legitimacy, but does not damage its pragmatic or moral legitimacy. To respond to a legitimacy crisis engendered by improper accounting practice, simply disassociating itself from the individuals involved in the illegality or creating a monitoring system is likely to make a significant contribution to the firm's regulative legitimacy. A business restructuring approach is not particularly appropriate to regulative legitimacy. However, as noted earlier, regulative legitimacy is derived from regulators rather than from market investors. The market response is not an effective indicator of regulators' perceptions. In the case of improper accounting practice, all four types of restructuring are likely to make a weaker contribution to the market response than they are in the cases of fraudulent financial reporting, embezzlement, and stock market manipulation. We therefore propose the following hypothesis:

Hypothesis 2c. For firms punished for improper accounting practice, all four types of restructuring have a weaker positive 


\section{FIGURE 2 \\ Fraud Types and Legitimacy Crisis}

\begin{tabular}{c|ccc}
\hline & $\begin{array}{c}\text { Fraudulent } \\
\text { financial } \\
\text { reporting }\end{array}$ & $\begin{array}{c}\text { Stock market } \\
\text { manipulation } \\
\text { and } \\
\text { embezzlement }\end{array}$ & $\begin{array}{c}\text { Improper } \\
\text { accounting } \\
\text { practice }\end{array}$ \\
\hline Regulative legitimacy & $\times$ & $\times$ & $\times$ \\
Pragmatic legitimacy & $\times$ & & \\
Moral legitimacy & & $\times$ & \\
\hline
\end{tabular}

effect on the market response than they do for firms punished for fraudulent financial reporting, embezzlement, or stock market manipulation.

The link between financial fraud and a legitimacy crisis is presented in Figure 2.

\section{METHODOLOGY}

\section{Sample and Data}

We test the hypotheses using a sample of Chinese listed firms punished for fraud from 1998 to $2004 .^{2}$ This is an ideal empirical context in which to address our theoretical concern. First, unlike in the Western world where financial fraud is relatively uncommon, financial fraud is not a rare phenomenon in the Chinese stock market (Zhang, 2004). From 1993, when China's stock market was established, until 2004, financial fraud was detected in over one-sixth of listed firms in China on at least one occasion (Zhang, 2004). ${ }^{3}$ Second, although some scholars suggest that the sanctions for financial fraud are not serious in China, crises arising from financial fraud cannot be ignored. This is because the stock market is regarded as a low-cost source of finance in China. Detecting and punishing financial fraud will induce market investors to challenge the firm's legitimacy and to sell its stock. To attract more capital, listed firms are concerned about market investors' perceptions of their legitimacy and reputation. Third, China has some unique cultural characteristics that mean financial fraud will inevitably precipitate a legitimacy crisis. These characteristics include the Confucian notion of saving face: listed firms will feel that they have lost face if they are found to have engaged in financial fraud $(\mathrm{Hu}, 1944)$ and have an incentive to recover from the legitimacy crisis it entails. Fourth, Chinese listed firms often turn to multiple forms of restructuring to respond to crises (Kam, Citron, \& Muradoglu, 2006). Whether the various restructuring strategies fraud firms adopt are appropriate responses to the legitimacy crises they face is a question that deserves the attention of firms, market investors, and scholars.

We use a four-step selection process to determine our sample. We first collect and double check records on penalties imposed on listed firms for financial fraud from the China Stock Market Accounting Research database (CSMAR) and the Web sites of the China Securities Regulatory Commission, the Shanghai Stock Exchange (SHSE), and the Shenzhen Stock Exchange (SZSE). We eliminate 21 firms listed on China's B-share market ${ }^{4}$ as this market is for foreign investors and has stricter regulations than those applicable to the A-share market in mainland China. We drop a further 16 firms which had their listings suspended within one year of being punished for financial fraud.

Second, when a firm is punished on multiple occasions within a short period (e.g., one year), the same restructuring plan can represent the firm's response to a series of penalties. To identify a unique penalty event for each restructuring, we treat the last penalty imposed before a focal restructuring in each year as the penalty event.

Third, to examine whether restructuring contributes equally to fraud firms and nonfraud firms, we identify a control firm for each fraud firm in the penalty year if the potential firm (1) has the same four-digit Global Industry Classification Standard (GICS) code as the fraud firm; (2) has net sales and total assets that are closest to those of the fraud firm (Agrawal et al., 1999; Farrell \& Whidbee, 2002; Fich \& Shivdasani, 2005); and (3) has not had a fraud event reported between 1994 and 2005.

Fourth, we collect all the restructuring announcements made within one year of the penalty date from CSMAR. We also collect financial data and daily stock prices from CSMAR, which are matched with corporate governance data from the China Center for Economic Research (CCER) database.

This leaves us with a final sample of 147 fraud firms and 140 nonfraud firms with full information in the regression model. Among the fraud firms, 123 firms have been punished on one occasion during the sample period, 16 have been punished twice, and 8 have been punished three times. Altogether, the 147 fraud firms account for 179 penalty events covering 748 instances of financial fraud issued between 1998 and 2004 (a firm may be punished for several instances of financial fraud in the same penalty announcement). We categorize the instances of fraud reported in CSMAR into three types of fraud. Table 1 displays the summary statistics for the fraud events. Of the fraud instances, 72.68 per cent involve fraudulent financial reporting, 1.75 per cent involve stock market manipulation, 9.15 per cent involve embezzlement, and 16.42 per cent involve improper accounting practice.

Firms often implement multiple restructurings to respond to a legitimacy crisis. Among the firms in our sample, 32.40 per cent of the fraud firms have conducted more than one restructuring after being punished for financial fraud and 46.39 per cent of the nonfraud firms have conducted more than one restructuring after the corresponding fraud firms have been punished for financial fraud. We take the restructuring announcement date as the event date. There might be multiple restructurings covering multiple types of restructuring on the same event date. In our sample, the 147 fraud firms have conducted 434 restructurings on 415 restructuring event dates, while the 140 nonfraud firms have conducted 371 restructurings on 329 restructuring event dates. Table 2 shows the number of restructurings implemented after penalties have been imposed for financial fraud.

The results are likely to be overstated if poorly performing firms are more likely to drop out of the analysis than are those that are performing well (or less poorly) or if the poor 
TABLE 1

Fraud Punishment on the Listed Firms

Fraud categories

Fraudulent financial reporting

Embezzlement

Stock market manipulation

Improper accounting practice

Total fraud instances

Number of penalty events

Number of fraud firms
Fraud instances in CSMAR

Number of cases

Fraudulent reporting

79

Inflated profit

52

Asset fabrication

12

A delay or postponement of report

291

Major failure to disclose information

106

Major shareholder embezzlement

25

Illegal guarantee

16

Unauthorized change in fund use

27

Fund provision violation

0

Insider trading

Stock price manipulation

Illegal hype

6

5

2

Others

122

748

179

147
TABLE 2

Number of Restructurings After Punishment

\begin{tabular}{lcc}
\hline $\begin{array}{l}\text { Number of } \\
\text { restructurings }\end{array}$ & \multicolumn{2}{c}{ Number of penalty events } \\
\cline { 2 - 3 } & $\begin{array}{c}\text { Fraud } \\
\text { firms }\end{array}$ & $\begin{array}{c}\text { Nonfraud } \\
\text { firms }\end{array}$ \\
\hline 1 & 58 & 75 \\
2 & 57 & 44 \\
3 & 35 & 21 \\
4 & 14 & 12 \\
5 & 9 & 6 \\
6 & 5 & 3 \\
7 & 1 & 1 \\
Total & 179 & 162 \\
\hline
\end{tabular}

performers are in the group that implement the least governance or operational change. However, such a survival bias is not an issue in the Chinese stock market because there are very few cases in which the firm is delisted (only 16 cases). We simply drop these cases out of our sample.

\section{Measures}

Dependent Variable. We use cumulative abnormal return (CAR) around the time of the restructuring announcement to proxy the success of legitimacy repair. CAR is calculated as the difference between the expected return on a stock and the actual return following the release of news to the market. Prior studies suggest that examining CAR will allow us to gauge how the group of society most directly affected by a firm's actions (i.e., market investors) perceives the legitimacy of the firm's actions (Agrawal \& Chadha, 2005; Arthaud-Day, Certo, Dalton, \& Dalton, 2006; Farber, 2005; Palmrose, Richardson, \& Scholz, 2004). This is because market investors' perceptions can be reflected in their trading behavior. For example, after the release of news of a firm's financial fraud, market investors will view the firm as illegitimate because they will believe that the firm does not have the ability and credibility required to work for their interests. They will immediately reduce their holdings of the firm's stock, which will lead to a negative CAR (Agrawal \& Chadha, 2005; Palmrose et al., 2004). In this case, a negative CAR is an indicator of legitimacy loss. In contrast, as shown by Farber (2005), after a fraud firm makes improvements in corporate governance, market investors perceive the firm to be more legitimate because they believe the firm can provide more value and be more credible. They will buy the firm's stock, which will lead to a positive CAR. In this case, a positive CAR indicates that the firm has regained legitimacy from market investors. Therefore, CARs can be used to indicate that a company has lost or regained social legitimacy from market investors. In this study, we expect a restructuring will lead to a higher CAR because it will help the firm regain legitimacy.

We calculate CARs for the fraud and nonfraud sample over a three-day event window from one day before to one day after the restructuring announcement day $t_{0}$ using standard event study methodology (Dodd \& Warner, 1983). Market model parameters are estimated over the prior 200day interval. Restructuring announcements include those declared by the fraud firm and by the nonfraud firm within one year of the date on which the fraud firm is subject to public sanctions. The detailed calculation procedure is presented in Appendix A. 
Independent Variables. Disassociation from an illegitimate organizational structure. This is proxied by the occurrence of CEO dismissal. CEO dismissal is coded 1 if the CEO is dismissed on the event date and 0 otherwise. We do not distinguish between voluntary resignations and involuntary dismissals because "face" and "harmony" are very important in China. CEOs who leave their posts tend to claim that they have done so voluntarily, even where they have actually been dismissed.

Creation of monitors. This is measured by two variables. First, we measure the creation of a better board as proxied by the appointment of a new board chairman, which is coded 1 if there is a new board chairman on the event date and 0 otherwise. Second, we measure the creation of better monitoring from block-shareholders. This is represented by a dummy variable coded 1 when the restructuring induces a change of ownership structure on the event date and 0 otherwise.

Disassociation from illegitimate business operations. This is measured by three dummy variables indicating the occurrence of asset divestment, subsidiary divestment, or debt restructuring. These variables are coded 1 when there is any asset divestment, subsidiary divestment, or debt restructuring on the event date and 0 otherwise.

Creation of valuable business operations. This is measured by two dummy variables indicating the occurrence of an asset acquisition or stock acquisition. These variables are coded 1 when there is an asset acquisition or stock acquisition on the event day and 0 otherwise.

Moderating Variables. Fraudulent financial reporting. This includes fraud offenses reported in the CSMAR database: fraudulent reporting, reporting inflated profit, asset fabrication, a delay or postponement of the annual report or other required report, and a major failure to disclose information.

Embezzlement. This includes fraud offenses such as major shareholder embezzlement, giving an illegal guarantee, unauthorized change in the use of funds, and fund provision violations.

Stock Market Manipulation. This includes fraud offenses such as insider trading, stock price manipulation, and creating illegal hype.

Improper Accounting Practice. The financial fraud offenses included in this category are erroneous accounting practices and reporting practices.

We use the number of offenses listed in the penalty announcement to measure the types of financial fraud committed by each firm.

The data for corporate restructurings and financial fraud are coded on the basis of the definitions, categories, and other information included in the CSMAR database. CSMAR is a database that is widely used to study Chinese listed firms. It has a clear scheme for the definitions and categories of corporate restructuring and financial fraud. Because the information CSMAR provides on listed firms is in Chinese, we employ a Chinese PhD student majoring in business policy to read the information in the CSMAR database and code the data. As the definitions and the categories of restructuring and financial fraud used in this study are mostly consistent with those in the CSMAR database, there is little ambiguity in the coding procedure. The coding scheme used for corporate restructuring and financial fraud is explained in Appendix B.

Control Variables. We control for alternative factors that could affect a firm's CAR. If a firm has been in an unfavorable situation for some time, market investors are likely to discount the stock. We use average growth opportunity, external financial need, and financial distress in years $(\mathrm{t}-2, \mathrm{t}-1)$ to proxy performance pressure (Wang, 2004). Growth opportunity is measured by the book-to-market ratio and growth in operating revenue. External financial need is measured by the need for external finance ${ }^{5}$ (Wang, 2004). Financial distress is measured by the long-term debt to assets ratio and the short-term debt to assets ratio. Firms that are penalized for fraud are likely to experience a negative market response. Any relatively positive gain seen in a fraud firm's stock following a restructuring announcement may be attributed to the fraud firm's stock already trading at a price lower than those of nonfraud firms. We therefore control for the market reaction following financial fraud penalties for both fraud firms and nonfraud firms. This is measured by the three-day CAR around the penalty announcement date. We also control for firm size, which is measured as the logarithm of total assets at the end of event year $\mathrm{t}-1$, because a larger firm may be viewed as more capable and thus enjoy a higher stock price. We control for current performance as measured by Return on Asset (ROA) at the end of year $\mathrm{t}-1$ because a positive market response may be based on market investors' positive evaluation of the firm's operating performance. ROA is calculated by dividing a company's annual earnings by its total assets. Industry is controlled for by 19 dummies $^{6}$ corresponding to four-digit GICS categories. The descriptive statistics and the correlation matrix are presented in Table 3.

\section{Statistical Approach}

We first conduct an event study to examine the market response to restructuring announcements made by fraud firms and nonfraud firms. We then regress the CARs calculated on the interaction between restructurings and types of fraud to examine whether the market responses to restructuring announcements differ for different types of fraud. Given that one firm may initiate multiple restructurings during the sample period, we use an OLS regression model clustered by firm.

\section{RESULTS}

\section{Event Study of Restructuring Announcements}

In the event study, we calculate CARs to measure the market response to restructuring announcements made by fraud firms and nonfraud firms within one year of being punished for fraud. The results are shown in Table 4.

Table 4 shows that among the types of restructuring considered, creation restructurings including ownership restructurings, stock acquisitions, and asset acquisitions lead to positive CARs for fraud firms at the .01, .01, and .1 significance levels, respectively. These positive CARs for 


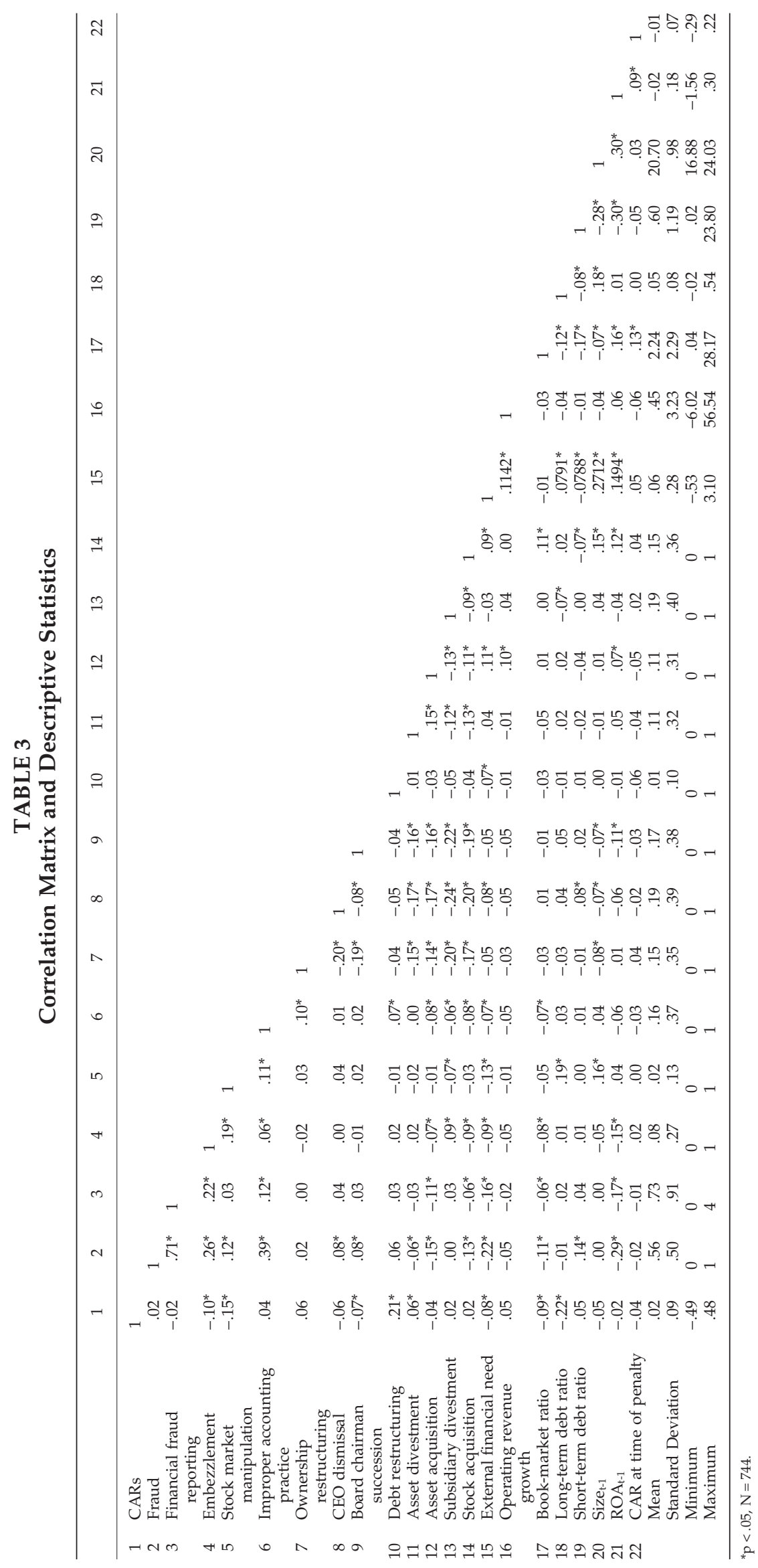


TABLE 4

Market Responses to Restructuring Events among Fraud Firms and Nonfraud Firms

\begin{tabular}{|c|c|c|c|c|c|}
\hline Restructuring event & $\begin{array}{l}\text { Fraud } \\
\text { firms (1) }\end{array}$ & Cases & $\begin{array}{l}\text { Nonfraud } \\
\text { firms (2) }\end{array}$ & Cases & $\begin{array}{l}p \text { Value } \\
(1)>(2)\end{array}$ \\
\hline CEO dismissal & .00 & 90 & .02 & 50 & .05 \\
\hline Board chairman succession & .00 & 81 & .02 & 45 & .08 \\
\hline Ownership restructuring & $.05^{* *}$ & 64 & .00 & 45 & .03 \\
\hline Subsidiary divestment & .02 & 80 & $.03+$ & 64 & .82 \\
\hline Asset divestment & .04 & 40 & $.04 \dagger$ & 45 & .51 \\
\hline Stock acquisition & $.04^{* * *}$ & 46 & .02 & 68 & .09 \\
\hline Asset acquisition & $.04^{* *}$ & 27 & -.01 & 53 & .01 \\
\hline Debt restructuring & $.27^{*}$ & 6 & -.05 & 1 & \\
\hline Restructuring events & $.02 * * *$ & 415 & $.02^{* * *}$ & 329 & .25 \\
\hline Number of sample firms & & 147 & & 140 & \\
\hline
\end{tabular}

$+\mathrm{p}<.1,{ }^{*} \mathrm{p}<.05, * * \mathrm{p}<.01,{ }^{* * *} \mathrm{p}<.001$.

fraud firms are significantly larger than those for nonfraud firms at the $.05, .1$, and .01 levels. In contrast, most of the forms of disassociation restructuring do not lead to significantly positive CARs for fraud firms. The exception is debt restructurings, which have a significantly positive impact on the CARs of fraud firms at the .05 level. These results support Hypothesis 1, suggesting that restructurings can be used as a response strategy to repair legitimacy after the firm is punished for financial fraud. The results also imply that although firms can turn to either disassociation restructurings or creation restructurings, market investors may value creation more than disassociation.

\section{Regression Analysis}

We then use CARs as the dependent variable to examine the market response to restructuring announcements made by the fraud firms and the nonfraud firms. The results are shown in Table 5. Model 1 is tested using the full sample, Model 2 is tested using the fraud firm sample, and Model 3 is tested using the nonfraud firm sample.

Among the forms of organizational creation restructuring, ownership restructuring is positively significant for the fraud firms (Model 2: $\beta=.08, \mathrm{p}<.01$ ) but shows no significance for the nonfraud firms. Among the forms of organizational disassociation restructuring, CEO dismissal is insignificant for both the fraud firms and the nonfraud firms. Among the forms of business creation restructuring, asset acquisition and stock acquisition have positive significance for the fraud firms (Model 2: $\beta=.04, \mathrm{p}<.1 ; \beta=.05, \mathrm{p}<.1$ ), but no significance for the nonfraud firms. Among the forms of business disassociation restructuring, asset divestment has positive significance for the fraud firms (Model 2: $\beta=.04$, $\mathrm{p}<.1$ ), but no significance for the nonfraud firms. Debt restructuring has positive significance for the fraud firms (Model 2: $\beta=.27, \mathrm{p}<.001$ ), but negative significance for the nonfraud firms (Model 3: $\beta=-.11, \mathrm{p}<.001$ ). These results suggest that the creation of a monitoring mechanism, the creation of valuable business operations, and disassociation from illegitimate business operations lead to a more positive market response among fraud firms than they do among nonfraud firms. Thus, Hypothesis 1 receives partial support. Moreover, when comparing the aggregate effect of disassociation and creation for the fraud firms, we find that the effect of business disassociation is not significantly different from that of business creation. ${ }^{7}$ In contrast, the effect of organizational creation is significantly stronger than that of organizational disassociation $(\mathrm{F}=7.14, \mathrm{p}<.01)$. These results suggest that market investors value organizational creation more than they do organizational disassociation and attach equal value to business creation and business disassociation.

We next examine the effectiveness of the various types of restructuring in the context of each type of fraud. We use the fraud firm subsample and interact the forms of restructuring with the types of fraud in the regression models. ${ }^{8}$ The results are shown in Table 6.

The Model 4 column in Table 6 shows the results for fraudulent financial reporting. The main effect of fraudulent financial reporting is negatively significant (Model 4: $\beta=-.09$, $\mathrm{p}<.05$ ). Debt restructuring is positively significant (Model 4 : $\beta=.28, p<.001)$. The main effects of the other forms of restructuring are not significant at all. When applied in the context of fraudulent financial reporting, subsidiary divestment and stock acquisition are positively related to the fraud firms' CARs (Model 4: $\beta=.11, \mathrm{p}<.05 ; \beta=.10, \mathrm{p}<.05$ ), while board chairman succession and CEO dismissal are positively significant (Model 4: $\beta=.08, \mathrm{p}<.1 ; \beta=.09, \mathrm{p}<.05$ ). However, the aggregate impact of organizational restructurings (disassociation + creation) in the context of fraudulent financial reporting is significantly lower than that of business restructurings (disassociation + creation) for the same type of fraud $(F=3.97, p<.05)$. These results suggest that all of the forms of restructuring including business disassociation, business creation, organizational disassociation, and organizational creation are helpful in repairing legitimacy following fraudulent financial reporting. However, business restructurings have a stronger impact on the success of efforts to repair legitimacy following fraudulent financial reporting than do organizational restructurings. Hypothesis $2 \mathrm{a}$ is thus supported. 
TABLE 5

Regression of CARs on Fraud Firms and Nonfraud Firms' Restructuring

\begin{tabular}{|c|c|c|c|c|c|c|}
\hline \multirow[t]{2}{*}{ CARs } & \multicolumn{2}{|c|}{ Model 1} & \multicolumn{2}{|c|}{ Model 2} & \multicolumn{2}{|c|}{ Model 3} \\
\hline & Coefficient & $\begin{array}{l}\text { Standard } \\
\text { error }\end{array}$ & Coefficient & $\begin{array}{l}\text { Standard } \\
\text { error }\end{array}$ & Coefficient & $\begin{array}{l}\text { Standard } \\
\text { error }\end{array}$ \\
\hline CEO dismissal & .02 & .01 & .03 & .03 & .01 & .01 \\
\hline Ownership restructuring & $.04^{* *}$ & .02 & $.08^{* *}$ & .03 & -.02 & .02 \\
\hline Board chairman succession & .02 & .01 & .03 & .03 & -.01 & .01 \\
\hline Asset divestment & $.04^{* *}$ & .01 & $.04 \dagger$ & .03 & .01 & .01 \\
\hline Subsidiary divestment & $.03^{*}$ & .01 & .04 & .03 & -.01 & .02 \\
\hline Debt restructuring & $.21^{* * *}$ & .03 & $.27^{* * *}$ & .04 & $-.11^{* * *}$ & .02 \\
\hline Asset acquisition & .01 & .01 & $.06^{*}$ & .02 & -.02 & .01 \\
\hline Stock acquisition & $.03^{*}$ & .01 & $.05+$ & .03 & .01 & .01 \\
\hline External financial need & $-.02+$ & .01 & $-.06^{*}$ & .02 & $-.02 t$ & .01 \\
\hline Main revenue change & .00 & .00 & .00 & .00 & $.00^{*}$ & .00 \\
\hline Book-market ratio & $-.00^{* *}$ & .00 & $-.00 \dagger$ & .00 & $.01^{*}$ & .00 \\
\hline Long-term debt ratio & $-.29^{* * *}$ & .05 & $-.40^{* * *}$ & .06 & .01 & .07 \\
\hline Short-term debt ratio & .00 & .00 & .00 & .00 & $.13^{* *}$ & .04 \\
\hline Size $_{\mathrm{t}-1}$ & .00 & .00 & $.02^{* *}$ & .01 & -.01 & .01 \\
\hline $\mathrm{ROA}_{\mathrm{t}-1}$ & -.01 & .02 & .02 & .02 & $-.12^{*}$ & .06 \\
\hline CAR at time of penalty & -.04 & .05 & -.09 & .06 & -.20 & .19 \\
\hline Constant & -.05 & .08 & $-.34^{* *}$ & .12 & .07 & .14 \\
\hline R-squared & .23 & .23 & .30 & .30 & .51 & .51 \\
\hline Adj. R-squared & .19 & .19 & .25 & .25 & .45 & .45 \\
\hline $\begin{array}{l}\text { F (Disassociation from business }= \\
\text { creation of business) }\end{array}$ & 1.05 & 1.05 & .67 & .67 & .33 & .33 \\
\hline $\begin{array}{l}\text { F } \text { (Disassociation from org. }= \\
\text { creation of monitors) }\end{array}$ & $4.61^{*}$ & $4.61^{*}$ & $7.14^{* *}$ & $7.14^{* *}$ & $3.20+$ & $3.20+$ \\
\hline Sample size & 744 & 744 & 415 & 415 & 329 & 329 \\
\hline
\end{tabular}

Notes: $t \mathrm{p}<.1,{ }^{*} \mathrm{p}<.05,{ }^{* *} \mathrm{p}<.01,{ }^{* * *} \mathrm{p}<.001$. All tests are two-tailed. Standard errors are given in parentheses.

Because of space limitations, we do not report the results for industry dummies in the table.

The Model 5 column in Table 6 shows the results for embezzlement. The main effect of embezzlement is significantly negative (Model 5: $\beta=-.18, \mathrm{p}<.05$ ). The main effects of ownership restructuring, debt restructuring, asset divestment, and asset acquisition are significantly positive (Model 5: $\beta=.08, p<.01 ; \beta=.28, \mathrm{p}<.001 ; \beta=.05, \mathrm{p}<.1 ; \beta=.04$, $\mathrm{p}<.1$ ). In the embezzlement context, board chairman succession and CEO dismissal are positively significant (Model $8: \beta=.18, \mathrm{p}<.05 ; \beta=.21, \mathrm{p}<.01)$. Among the interaction terms between embezzlement and business restructurings, only the interaction between embezzlement and subsidiary divestment shows positive significance (Model 8: $\beta=.18$, $\mathrm{p}<.05)$. The aggregate effect of organizational restructurings (disassociation + creation) in the embezzlement context is significantly greater than that of business restructurings (disassociation + creation) in the context of the same type of fraud $(\mathrm{F}=6.08, \mathrm{p}<.05)$. These results suggest that organizational disassociation, organizational creation, and business disassociation contribute to legitimacy repair in the case of embezzlement. However, organizational restructurings are more effective in repairing legitimacy following embezzlement than are business restructurings. Hypothesis $2 b$ is therefore supported.

The Model 6 column in Table 6 presents the results for stock market manipulation. The main effect of stock market manipulation is negatively significant (Model 6: $\beta=-.09$, $\mathrm{p}<.05)$. Ownership restructuring, debt restructuring, asset divestment, asset acquisition, and stock acquisition show positive significance (Model 6: $\beta=.09, \mathrm{p}<.01 ; \beta=.26, \mathrm{p}<.05$; $\beta=.05, \mathrm{p}<.05 ; \beta=.05, \mathrm{p}<.05 ; \beta=.05, \mathrm{p}<.05)$. The interaction term between CEO dismissal and stock market manipulation is positively significant (Model 6: $\beta=.13, \mathrm{p}<.1$ ). These results suggest that organizational disassociation is helpful in repairing legitimacy following stock market manipulation. Among the organizational creation strategies, board chairman succession is not significant in the context of stock market manipulation, whereas ownership restructuring is negatively significant (Model 6: $\beta=-.28, \mathrm{p}<.05$ ). This result, while unexpected, can be explained. Because stock market manipulation is often associated with equity transactions 


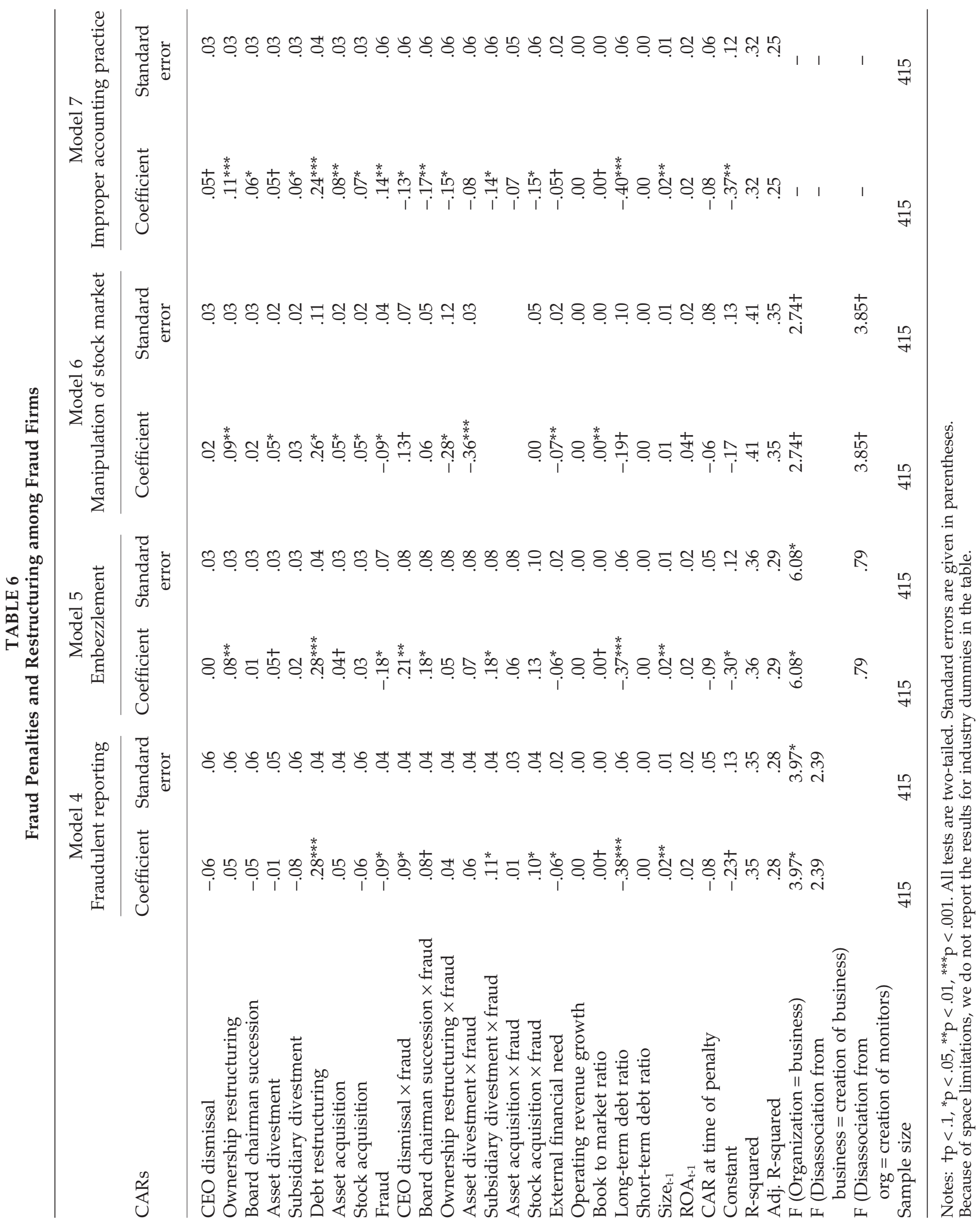


which lead to a change in the ownership structure, it is reasonable for the market to view ownership restructuring as a form of stock market manipulation. Among business restructurings, none other than asset divestment interacted with stock market manipulation have a significantly negative effect (Model 6: $\beta=-.36, \mathrm{p}<.001$ ). These results suggest that business restructurings do not lead to a positive market response if the firm is punished for stock market manipulation. The aggregate effect of organizational restructurings (disassociation + creation) in the context of stock market manipulation is significantly stronger than that of business restructurings (disassociation + creation) in the same context $(\mathrm{F}=2.74 ; \mathrm{p}<.1)$. These results also support Hypothesis $2 \mathrm{~b}$.

The Model 7 column in Table 6 shows the results for improper accounting practice. The main effect of improper accounting practice is significantly positive (Model 7: $\beta=.14$, $\mathrm{p}<.01)$. The main effects of ownership restructuring, CEO dismissal, board chairman succession, debt restructuring, asset divestment, subsidiary divestment, asset acquisition, and stock acquisition show positive significance (Model 7: $\beta=.11, \mathrm{p}<.001 ; \beta=.05, \mathrm{p}<.1 ; \beta=.06, \mathrm{p}<.05 ; \beta=.24$, $\mathrm{p}<.001 ; \beta=.05, \mathrm{p}<.1 ; \beta=.06, \mathrm{p}<.05 ; \beta=.08, \mathrm{p}<.01 ; \beta=.07$, $\mathrm{p}<.05)$. The interactions between improper accounting practice and forms of restructuring including board chairman succession, CEO dismissal, subsidiary divestment, and stock acquisition are negatively related to CARs (Model 7: $\beta=-.17, \mathrm{p}<.01 ; \beta=-.13, \mathrm{p}<.05 ; \beta=-.15, \mathrm{p}<.05 ; \beta=-.14$, $\mathrm{p}<.05 ; \beta=-.15, \mathrm{p}<.05)$. These results suggest that restructurings have a weaker effect on repairing legitimacy following improper accounting practice than they do following instances of fraudulent financial reporting, embezzlement, and stock market manipulation.

In most of the model results reported in Tables 5 and 6, external financial need, the book-market ratio, and the longterm debt to assets ratio show negative significance, suggesting that financial requirements, high growth, and financial distress are negatively related to market performance among fraud firms. In Models 2, 4, 5, 6, and 7, size is positively significant for stock performance, suggesting that market investors perceive large fraud firms to be more able to respond to a legitimacy crisis and reward them with higher valuations. ROA shows positive significance (Model 6: $\beta=-.04, \mathrm{p}<.1)$.

\section{DISCUSSION}

This study begins by noting that although scholars have focused on organizational crisis management for several decades, it remains unclear why some reactions are useful in overcoming certain types of crisis, while others are not. We seek to answer this question by identifying the mechanism behind stakeholder perceptions of the different types of crisis and the organizational reactions to them. We specifically focus on one type of crisis: that arising from the imposition of penalties for financial fraud. We examine the effectiveness of various forms of restructuring aimed at repairing legitimacy after the firm has been punished for different types of financial fraud.

We first show that fraud firms initiate restructuring plans to signal that they are disassociating themselves from ille- gitimate forms of business or organizational influences or to create valuable business operations or a monitoring system. As the purpose of these forms of restructuring are clearer in fraud firms than in nonfraud firms, they all lead to a more positive market response among fraud firms than they do among nonfraud firms. Restructuring can thus be an effective signaling strategy to repair legitimacy after a firm is punished for financial fraud. In examining the effectiveness of disassociation versus creation, we find that while market investors value the creation of valuable business operations and disassociation from illegitimate business operations to the same extent, they value the implementation of a better monitoring system more highly than they do disassociation from individuals involved in illegitimate conduct. This result is consistent with the study of Boeker (1992), who suggests that in firms with performance issues but high CEO power, CEO turnover tends to be a ceremonial or scapegoating tactic. This study also supports the view that market investors may view disassociation from individuals involved in illegitimate conduct as a ceremonial tactic and require some discount for it.

We then link the effectiveness of restructurings with financial fraud crises via social legitimacy. The detection of financial fraud may hurt a firm's legitimacy in a number of dimensions. When the firm is punished for financial fraud, the firm's regulative legitimacy will certainly suffer. We also show that financial fraud can be classified into three types based on the antecedents of this type of corporate malfeasance and that they may hurt different dimensions of organizational legitimacy.

Fraudulent financial reporting is motivated by pressure to perform. The detection of fraudulent financial reporting will lead market investors to question the firm's ability to provide utility, as a result of which the firm's pragmatic legitimacy will be challenged. For this type of financial fraud, a restructuring of business operations will be more effective than a restructuring of the organizational structure in repairing the firm's legitimacy. The firm can initiate a restructuring to disassociate itself from illegitimate business operations by, for example, divesting itself of inefficient assets, projects, or even subsidiaries. Alternatively, the firm can create value through acquiring assets or firms to allow it to enter new businesses. In so doing, the firm is expected to increase cash flow, to reduce operating costs, and to focus on a more efficient business portfolio. The firm therefore signals that it can improve its operations and provide market investors with more tangible rewards (Suchman, 1995). Its pragmatic legitimacy will be restored.

Embezzlement is motivated by the incentive of controlling shareholders to seize the firm's wealth for their own use. Stock market manipulation is motivated by the incentive of Top Management Team members or controlling shareholders to gain from manipulating the stock price, insider trading, or illegal hype. The detection of these types of fraud will lead market investors to believe that insiders are intentionally working against their interest, calling the firm's moral legitimacy into question. For such types of financial fraud, a restructuring of the firm's organizational structure is more effective than a restructuring of its business operations in repairing the firm's legitimacy. Given the absence of clear outcome measures for moral legitimacy, the firm has to 
address the legitimacy of individuals or structural legitimacy. The firm can initiate a restructuring to disassociate itself from the individuals who are responsible for the illegal behavior such as the CEO. Alternatively, the firm can create an organizational structure that enables it to monitor insiders by changing the board chairman or reducing the ultimate controller's voting power through an ownership restructuring. This will allow the firm to convince market investors that the organization has appropriate individuals and structures in place and that it will act beyond reproach going forward, thus restoring its moral legitimacy. Our results also give empirical support to prior studies which report higher leadership turnover after fraud revelations (Agrawal et al., 1999; Livingston, 1997).

Ownership restructuring is a special form of restructuring. As shown by our results, ownership restructuring leads to a positive CAR for all types of fraud. However, the interactions between ownership restructuring and fraudulent financial reporting and embezzlement are not significant. These results, which are inconsistent with our prediction, can be explained by the way in which ownership restructurings can be used to address both pragmatic legitimacy and moral legitimacy. First, the dominant stockholder can encourage the firm to commit fraud as other shareholders are not in a position to play an effective monitoring role (Chen et al., 2005). Ownership restructurings can result in better monitoring from other block shareholders than business restructurings, as we predict in Hypothesis 2b. Furthermore, ownership restructuring is often realized by introducing new owners into the firm. New owners often bring in additional resources, thus alleviating financial pressure. Hence, ownership restructuring is a strategy that can be used to address both pragmatic legitimacy and moral legitimacy.

Improper accounting practice, which includes improper financial reporting, improper practice on the part of the CEO or the board of directors, etc., is not motivated by pressure to perform or insiders' manipulation of the firm's wealth. It damages the firm's regulative legitimacy, but does not have a negative impact on its pragmatic or moral legitimacy. We have shown that all the forms of restructuring we examine have a weaker effect on legitimacy repair in the case of improper accounting practice than they do in the cases of fraudulent financial reporting, embezzlement, and stock market manipulation. This result is not unexpected because regulative legitimacy is derived from regulators rather than from market investors. Market response is not an effective measure of success in repairing regulative legitimacy.

\section{CONCLUSION}

This study examines the effectiveness of different forms of restructuring implemented to repair legitimacy after a firm has been punished for different types of financial fraud. We make three major contributions to the organizational crisis and organizational legitimacy literature.

First, although much effort has been made to examine organizational crises, the mechanisms underlying the social dimension of organizational crises remain unclear. This study links corporate crises with the social legitimacy construct. We argue that all types of financial fraud hurt the regulative legitimacy of the firm and show that different types of financial fraud have different antecedents. Furthermore, different types of financial fraud can damage different dimensions of social legitimacy. Fraudulent financial reporting, which is motivated by performance pressure, will hurt the pragmatic legitimacy of the firm. On the other hand, stock market manipulation and embezzlement, which are generally motivated by insiders' interests, will harm the firm's moral legitimacy. Improper accounting practice, which is not motivated by performance pressure or insiders' interests, hurts only the regulative legitimacy of the organization.

The second major contribution this study makes is to provide a more comprehensive list of responsive restructurings to repair legitimacy. The restructuring strategies discussed in prior legitimacy literature mainly centre on organizational structure, i.e., disassociation from key individuals, processes, and structures, and the creation of monitors (Suchman, 1995). We introduce restructurings of business operations to the list of measures that can be taken to restore legitimacy. Our conception of restructuring according to the two dimensions of content and form allows us to extend the menu of potential restructuring strategies to four categories: disassociation from an illegitimate organizational structure, disassociation from illegitimate business operations, the creation of better monitoring, and the creation of valuable business operations.

Third, this study links the effectiveness of restructurings with corporate crises resulting from financial fraud via social legitimacy. We show that to restore its legitimacy, the firm should initiate a restructuring according to the nature of the fraud and address the pertinent dimensions of legitimacy. Organizational disassociation and organizational creation are more effective means of repairing moral legitimacy following embezzlement or stock market manipulation, while business disassociation and business creation are more effective strategies for repairing pragmatic legitimacy in the wake of fraudulent financial reporting. Market investors value organizational creation more than they do organizational disassociation, while they attribute equal value to business creation and business disassociation initiatives.

Despite the advances this study makes, it is subject to a number of limitations. First, we do not identify a direct indicator of legitimacy. The best way to measure legitimacy is to use the stakeholders' perceptions (including those of market investors and regulators) of each dimension of legitimacy after the firm is punished for financial fraud or announces a restructuring. However, because our sample is based on past events (1998-2004), we cannot accurately assess the perceptions of stakeholders at the time. We are therefore obliged to measure the success of legitimacy restoration efforts using a second-best approach by assessing market reaction. The effectiveness of this indicator depends to a great extent on the efficiency of the market, which may be doubtful in the case of China. However, substantial empirical evidence indicates that the stock market is weakform and semi-strong-form efficient and that new information is rapidly incorporated into prices (Chen, Chen, \& Su, 2001; Wei \& Fan, 2000). This gives us confidence that stock returns can be used to measure market investors' views of firms' actions and are an acceptable indicator of market investors' views on legitimacy. 
The second limitation of this study is that because financial fraud is often a result of corporate crime, the firm's regulative legitimacy will be challenged. However, because regulative legitimacy flows from regulators rather than from market investors, market response cannot be an effective measure for regulative legitimacy. This prevents us from considering regulative legitimacy in this study.

The third limitation we would highlight is our use of a dummy that indicates the occurrence of each type of restructuring on the event date to represent the various forms of restructuring. This is not a perfect measure because on an event date, each type of restructuring may involve multiple transactions with different values. While the best way of measuring restructurings is to use the value they bring to the firm, we do not have this information available to us. Another alternative is to use the number of each type of restructuring. However, it is difficult to define the number of each type of restructuring if a certain type of restructuring is composed of several transactions. For example, a firm may announce that it is divesting several obsolete assets to several buyers. It is difficult to define this restructuring as either a single divestiture or as several divestitures. Even we define it as several divestitures, it is doubtful that market investors will value two asset divestitures more highly than one asset divestiture if we do not incorporate the value of the assets divested. In the sense that restructuring is a signaling strategy aimed at repairing the firm's legitimacy, market investors should be more sensitive to its occurrence than to the value or number of restructurings. We therefore believe that using dummies to indicate the occurrence of restructurings on the event date represents a second-best approach.

The fourth limitation we have identified is that we examine only the content of restructurings while ignoring their depth. According to prior studies, some restructurings are superficial actions taken to manipulate earnings (Ding, Zhang, \& Zhang, 2007; Jian \& Wong, 2006; Jiang \& Wang, 2003; Liu \& $\mathrm{Lu}, 2007)$. It is possible that market investors are able to identify such superficial restructurings and require a discount (Suchman, 1995). Our results also give us some clues. We show that CEO dismissal is less valued by market investors as it may be viewed as a ceremonial tactic. This could constitute a potential opportunity to extend the current literature. A fifth shortcoming of this study is that it is conducted in a single country; we expect researchers to test the generalizability of our results in other countries in future.

Despite these limitations, this study is among the first to seek to link corporate crises resulting from financial fraud with the effectiveness of responsive restructurings via social legitimacy. It has some important implications for corporate decision makers and provides a sociological basis for improved recommendations for effective crisis management. When a firm is required to deal with a crisis after being publicly sanctioned for financial fraud or a similar incident, it is important to initiate a restructuring plan according to the nature of the legitimacy crisis. We also show that market investors value the creation of monitoring mechanisms more highly than they do disassociation from individuals involved in illegal conduct. It is clear that this is where firms tainted by fraud should concentrate their restructuring efforts if they seek to regain their moral legitimacy.

\section{ACKNOWLEDGEMENTS}

We are thankful to the chief editor Professor William Judge, associate editor Professor Igor Filatotchev and two anonymous reviewers for helpful comments during the review process.

\section{NOTES}

1. Manipulators can potentially include any informed party such as a corporate insider, broker, underwriter, large shareholder or market maker (Aggarwal \& Wu, 2003). In this study, we examine only penalties for fraud among firms. Therefore, corporate insiders and block shareholders are the two groups of potential manipulators.

2. All firms that have been found to have committed financial fraud have been punished, but the seriousness of the penalties imposed varies. However, as the level of punishment is beyond the scope of this study, we do not provide the relevant information.

3. Zhang (2004) reports that from 1993 to 2003 , of the more than 1200 firms listed on the Shanghai and Shenzhen stock exchanges, approximately 200, or one-sixth, were subject to enforcement action by the China Securities Regulatory Commission (CSRC), the Shenzhen Stock Exchange (SZSE), or the Shanghai Stock Exchange (SHSE). We cross-check this ratio based on the CSMAR fraud database. According to our calculation, from 1993 to 2003, 188 out of 1224 A-share companies were punished for financial fraud. This equates to a ratio of 15.49 per cent, which is quite similar to that reported by Zhang (2004). We further calculate the ratio for 1993-2004 and find that 2,33 out of 1,363 A-share companies were punished for financial fraud between 1993 and 2004. This equates to a ratio of 16.87 per cent, or more than $1 / 6$.

4. There are three types of stock in the Chinese stock market, i.e., A, $\mathrm{B}$, and $\mathrm{H}$ shares. Both the $\mathrm{A}$ and $\mathrm{B}$ markets are based in mainland China. A shares, which are denominated in RMB, the Chinese currency, are traded exclusively by Chinese citizens. B shares, which are denominated in US dollars on the SHSE and in HK dollars on the SZSE, were allowed to be traded by foreign investors only before February 2001. From February 2001, the B markets were opened up to Chinese citizens who have deposit accounts in foreign currencies. H shares are traded on the Stock Exchange of Hong Kong and are denominated in HK dollars.

5. We calculate the firm's projected need for outside capital based on the externally financed growth rate constructed by Demirguc-Kunt and Maksimovic (1998). Specifically, the externally financed growth rate is a firm's asset growth rate in excess of the maximum growth rate that can be supported by the firm's internally available capital. The maximum internal growth rate is the growth rate if a firm relies only on its internal resources and maintains its dividend:

$$
\frac{R O A_{1}}{1-R O A_{t}}
$$

It is obtained by assuming that the firm retains all its earnings. Where $R O A_{t}$ is the firm's return on assets (the ratio of earnings after taxes and interest to total assets), the firm's external financial need can be proxied by:

$$
\frac{R O A_{t}-R O A_{t-1}}{R O A_{t-1}}-\frac{R O A_{t-1}}{1-R O A_{t-1}}
$$

6. The Global Industry Classification Standard (GICS) was developed by MSCI, a premier independent provider of global indices and benchmark-related products and services, and Standard \& Poor's (S\&P), an independent international financial data and investment services company and a leading provider of global equity indices. The GICS structure consists of 10 sectors, 24 industry groups, 68 industries, and 154 sub-industries. GICS 
industries included in the sample are: 1,010, energy, 1,510, raw materials, 2,010, capital products, 2,030, transportation, 2,510, autos, 2,520, appliances and clothes, 2,020, commercial services and providers, 2,530, consumer services, 2,540, media, 2,550, retail, 3,010, food and main product retail, 3,020, food, drink, and tobacco, 3,520, pharmacy and biotech, 4,020, financial, 4,040, property, 4,510, software and services, 4,520, IT, technology, hardware, and equipment, 5,510, public industry.

7. We do not incorporate the debt restructuring when comparing the effect of business disassociation with that of business creation for two reasons: (1) there are only six debt restructuring announcements in our sample; (2) debt restructuring has a very large effect. It will conceal the relative contribution difference between the creation of a business portfolio and disassociation from business portfolio.

8. We do not incorporate the interaction between debt restructuring and fraud types for two reasons: (1) there are only six debt restructuring announcements in our sample; (2) as shown in Model 2, the effect of aggregated organizational restructurings is significantly weaker than that of aggregated business restructuring at the .01 level. When debt restructuring is not considered, the difference is not significant at all. This suggests that debt restructuring has a significant larger effect on the market response for fraud firms than it does for other restructurings. Including debt restructuring would conceal the relative contribution difference between organizational restructurings and business restructurings.

\section{APPENDIX A: EVENT STUDY}

We calculate cumulative abnormal return (CAR) following Dodd and Warner's procedure (1983).

1. Estimate the daily abnormal return (AR)

AR represents the return earned by the firm adjusted for the "normal" return process. It is estimated from the market model:

$$
R_{i t}=\alpha_{i}+\beta_{i} R_{m t}+\varepsilon_{i t}
$$

where $R_{i t}=$ the daily return including dividends on the share price for firm $i$ at time $t$ from the CSMAR individual stock daily return database. $R_{m t}=$ the return on a market portfolio of stocks weighted by common stock on day $t$ from the CSMAR daily stock market return database. $\alpha_{i}$ and $\beta_{i}$ are OLS parameter estimates obtained from the regression of $R$ it on Rmt over the 200 days preceding the event.

Based on the estimated equation (1), $A R$ for the ith firm is estimated by:

$$
A R_{i t}=R_{i t}-\left(\alpha_{i}+\beta_{i} R_{m t}\right)
$$

2. Calculate the cumulative abnormal return (CAR)

To capture the full effect of publications, CAR is calculated over a 3-day event window from one day before to one day after the announcement day $t_{0}$.

Following Dodd and Warner (1983), we first compute a standardized abnormal return (SAR) where the abnormal return is standardized by its standard deviation:

$$
\begin{aligned}
S A R_{i t} & =A R_{i t} / S D_{i t} \text { with } S D_{i t} \\
& =\left\{S_{i}^{2} \times\left[1+1 / T\left(R_{m t}-R_{m}\right)^{2} / \sum_{t-1}^{T}\left(R_{m t}-R_{m}\right)^{2}\right]\right\}^{0.5}
\end{aligned}
$$

where $S_{i}^{2}$ is the residual variance from the market model as computed for firm $i$ and $R_{m}$ is the mean return on the market portfolio calculated during the estimation period of $T$ days. The standardized abnormal return can then be cumulated over an event window of $k$ days to derive the cumulative

\begin{tabular}{|c|c|c|c|}
\hline Variable & Coding in this study & CSMAR categories involved & Source \\
\hline $\begin{array}{l}\text { Asset } \\
\text { divestment }\end{array}$ & $\begin{array}{l}\text { Has the firm been involved in selling } \\
\text { tangible fixed assets or intangible assets } \\
\text { including stock, equipment, real estate, } \\
\text { property, a product line, or a brand, or in } \\
\text { selling investments in firms in which the } \\
\text { firm does not have majority voting power? } \\
1=\text { yes, } 0=\text { no }\end{array}$ & $\begin{array}{l}\text { Selling assets } \\
\text { Selling investments } \\
\text { Swapping assets }\end{array}$ & $\begin{array}{l}\text { CSMAR M\&A and } \\
\text { restructuring } \\
\text { database }\end{array}$ \\
\hline $\begin{array}{l}\text { Subsidiary } \\
\text { divestment }\end{array}$ & $\begin{array}{l}\text { Has the firm been involved in selling } \\
\text { investments in a subsidiary in which the } \\
\text { firm has majority voting power? } \\
1=\text { yes, } 0=\text { no }\end{array}$ & $\begin{array}{l}\text { Selling investments } \\
\text { Swapping investments }\end{array}$ & $\begin{array}{l}\text { CSMAR M\&A and } \\
\text { restructuring } \\
\text { database }\end{array}$ \\
\hline $\begin{array}{l}\text { Debt } \\
\text { restructuring }\end{array}$ & $\begin{array}{l}\text { Has the firm been involved in a debt } \\
\text { forgiveness, a debt rescheduling, and/or } \\
\text { conversion of a portion of debt into } \\
\text { equity? } \\
1 \text { = yes, } 0 \text { = no }\end{array}$ & $\begin{array}{l}\text { Debt restructuring } \\
\text { Swapping assets }\end{array}$ & $\begin{array}{l}\text { CSMAR M\&A and } \\
\text { restructuring } \\
\text { database }\end{array}$ \\
\hline
\end{tabular}
abnormal return (CAR) for each firm:

$$
C A R_{i}=1 / k^{0.5} \sum_{t=1}^{k} S A R_{i t}
$$

\section{APPENDIX B: CODING OF RESTRUCTURINGS AND FINANCIAL FRAUD}


APPENDIX B: Continued

\begin{tabular}{|c|c|c|c|}
\hline Variable & Coding in this study & CSMAR categories involved & Source \\
\hline $\begin{array}{l}\text { Asset } \\
\text { acquisition }\end{array}$ & $\begin{array}{l}\text { Has the firm been involved in acquiring } \\
\text { tangible fixed assets or intangible assets } \\
\text { including stock, equipment, real estate, } \\
\text { property, a product line, or a brand? } \\
1 \text { = yes, } 0=\text { no }\end{array}$ & Acquiring assets & $\begin{array}{l}\text { CSMAR M\&A and } \\
\text { restructuring } \\
\text { database }\end{array}$ \\
\hline $\begin{array}{l}\text { Stock } \\
\text { acquisition }\end{array}$ & $\begin{array}{l}\text { Has the firm been involved in making } \\
\text { investments and acquiring ownership } \\
\text { rights in firms or buying stock through } \\
\text { the stock market? } \\
1=\text { yes, } 0=\text { no }\end{array}$ & Acquiring investments & $\begin{array}{l}\text { CSMAR M\&A and } \\
\text { restructuring } \\
\text { database }\end{array}$ \\
\hline CEO dismissal & $\begin{array}{l}\text { Is there a CEO dismissal? } \\
1=\text { yes, } 0=\text { no }\end{array}$ & CEO dismissal & $\begin{array}{l}\text { CSMAR Corporate } \\
\text { Governance } \\
\text { Database }\end{array}$ \\
\hline $\begin{array}{l}\text { Ownership } \\
\text { restructuring }\end{array}$ & $\begin{array}{l}\text { Is there a change in owner or in the } \\
\text { owners' shareholdings? } \\
1=\text { yes, } 0=\text { no }\end{array}$ & Ownership restructuring & $\begin{array}{l}\text { CSMAR M\&A and } \\
\text { restructuring } \\
\text { database }\end{array}$ \\
\hline $\begin{array}{l}\text { Board } \\
\text { chairman } \\
\text { succession }\end{array}$ & $\begin{array}{l}\text { Is there a board chairman succession? } \\
1=\text { yes, } 0=\text { no }\end{array}$ & Board chairman succession & $\begin{array}{l}\text { CSMAR Corporate } \\
\text { Governance } \\
\text { Database }\end{array}$ \\
\hline $\begin{array}{l}\text { Fraudulent } \\
\text { financial } \\
\text { reporting }\end{array}$ & $\begin{array}{l}\text { How many of the following items appear } \\
\text { in a penalty announcement for a firm? } \\
\text { (Fraudulent reporting, inflated profit, } \\
\text { asset fabrication, a delay or } \\
\text { postponement of the annual report or } \\
\text { another required report, and major } \\
\text { failure to disclose information) }\end{array}$ & $\begin{array}{l}6=\text { fraudulent reporting, } 2=\text { inflated } \\
\text { profit, } 3=\text { asset fabrication, } 5=a \\
\text { delay or postponement of the } \\
\text { annual report or another required } \\
\text { report, and } 8=\text { major failure to } \\
\text { disclose information }\end{array}$ & $\begin{array}{l}\text { CSMAR corporate } \\
\text { financial fraud } \\
\text { database }\end{array}$ \\
\hline Embezzlement & $\begin{array}{l}\text { How many of the following items appear } \\
\text { in a penalty announcement for a firm? } \\
\text { (Major shareholder embezzlement, } \\
\text { illegal guarantee, unauthorized change } \\
\text { in fund use, and fund provision } \\
\text { violation) }\end{array}$ & $\begin{array}{l}9=\text { major shareholder embezzlement, } \\
12=\text { illegal guarantee, } \\
4=\text { unauthorized change in fund } \\
\text { use, and } 7=\text { fund provision } \\
\text { violation }\end{array}$ & $\begin{array}{l}\text { CSMAR corporate } \\
\text { financial fraud } \\
\text { database }\end{array}$ \\
\hline $\begin{array}{l}\text { Stock market } \\
\text { Manipulation }\end{array}$ & $\begin{array}{l}\text { How many of the following items appear } \\
\text { in a penalty announcement for a firm? } \\
\text { (Insider trading, stock price } \\
\text { manipulation, and illegal hype) }\end{array}$ & $\begin{array}{l}1=\text { insider trading, } 10=\text { stock price } \\
\text { manipulation, and } 13=\text { illegal hype }\end{array}$ & $\begin{array}{l}\text { CSMAR corporate } \\
\text { financial fraud } \\
\text { database }\end{array}$ \\
\hline $\begin{array}{l}\text { Improper } \\
\text { accounting } \\
\text { practice }\end{array}$ & $\begin{array}{l}\text { How many of the following items appear } \\
\text { in a penalty announcement for a firm? } \\
\text { (Erroneous accounting practice or } \\
\text { reporting practice) }\end{array}$ & $14=$ Others & $\begin{array}{l}\text { CSMAR corporate } \\
\text { financial fraud } \\
\text { database }\end{array}$ \\
\hline
\end{tabular}

Notes:

1 Most of the coding for restructurings is the same as CSMAR coding. The only difference is that CSMAR has a category of asset swaps in which firms swap assets and investments with other firms' assets and investments. We re-examine the content of the asset swap. When the asset swap is associated with a sale of tangible fixed assets or intangible assets including stock, equipment, real estate, property, a product line, or a brand, or with a sale of investments in firms in which the firm does not have majority voting power, we code the firm as being involved in an asset divestment. When the asset swap is associated with debt forgiveness, a debt rescheduling, and/or conversion of a portion of debt into equity, we code the firm as being involved in a debt restructuring. When the asset swap is associated with an acquisition of tangible fixed assets or intangible assets including stock, equipment, real estate, property, a product line, or a brand, we code the firm as being involved in an asset acquisition. When the asset swap is associated with investment in and the acquisition of ownership rights in firms or with buying stock through the stock market, we code the firm as being involved in a stock divestment.

2 In CSMAR coding for financial fraud, there is an additional type of fraud, i.e., fraud in the listing procedure $(11=$ fraud in listing procedure). However, no firm was punished for this type of fraud from 1998 to 2004. 


\section{REFERENCES}

Aggarwal, R. K. \& Wu, G. J. 2003. Stock market manipulationTheory and evidence. AFA 2004. San Diego Meetings. Available at SSRN: http://ssrn.com/abstract $=474582$ or DOI: 10.2139 / ssrn.474582 (accessed March 11, 2003).

Agrawal, A. \& Chadha, S. 2005. Corporate governance and accounting scandals. Journal of Law and Economics, 48: 371-406.

Agrawal, A., Jaffe, J. F., \& Karpoff, J. M. 1999. Management turnover and governance changes following the revelation of fraud. Journal of Law and Economics, 42: 309-342.

Arthaud-Day, M., Certo, S. T., Dalton, C. M., \& Dalton, D. R. 2006. A changing of the guard: Executive and director turnover following corporate earnings restatements. Academy of Management Journal, 49: 1119-1136.

Beasley, M. S. 1996. An empirical analysis of the relation between the board of director composition and financial statement fraud. Accounting Review, 71: 443-465.

Beasley, M. S., Carcello, J. V., Hermanson, D. R., \& Lapides, P. D. 2000. Fraudulent financial reporting: Consideration of industry traits and corporate governance mechanisms. Accounting Horizons, 14: 441-454.

Bebchuk, L. A. \& Bar-Gill, O. 2003. Misreporting corporate performance. Working paper, Harvard University.

Boeker, W. 1992. Power and managerial dismissal: Scapegoating at the top. Administrative Science Quarterly, 37: 400-421.

Breitsohl, H. Linking organizational crises and reactive strategies via dimensions of legitimacy, Schumpeter Discussion Papers, 2009-005. http://elpub.bib.uni-wuppertal.de/edocs/ dokumente/fbb/wirtschaftswissenschaft/sdp/sdp09/ sdp09005.pdf (accessed April 2009).

Chandler, A. D. 1962. Strategy and structure: Chapters in the History of the industrial enterprise. Cambridge: MIT Press.

Chen, C. J. P., Chen, S. M., \& Su, X. J. 2001. Is accounting information value-relevant in the emerging Chinese stock market. Journal of International Accounting, Auditing and Taxation, 10(1): 1-22.

Chen, G. M., Firth, M., Gao, N., \& Rui, O. 2005. Do ownership structure and governance mechanisms have an effect on corporate fraud in China's listed firms. SSRN: http://ssrn.com/ abstract $=728945$ or doi:10.2139/ssrn.728945 (accessed January 2005).

Claessens, S., Djankov, S., Fan, J. P. H., \& Lang, L. H. P. 2002. Disentangling the incentive and entrenchment effects of large shareholdings. Journal of Finance, 57: 2741-2771.

Clinard, M. B. \& Quinney, R. 1973. Criminal behavior systems: A typology. New York: Holt, Rinehart \& Winston.

Comment, R. \& Jarrell, G. A. 1995. Corporate focus and stock returns. Journal of Financial Economics, 37: 67-87.

Demirguc-Kunt, A. \& Maksimovic, V. 1998. Law, finance, and firm growth. Journal of Finance, 53: 2107-2137.

Ding, Y., Zhang, H., \& Zhang, J. 2007. Private vs. state ownership and earnings management: evidence from Chinese listed companies. Corporate Governance, 15: 223-238.

Dodd, P. \& Warner, J. B. 1983. On corporate governance - A study of proxy contests. Journal of Financial Economics, 11: 401-438.

Elsbach, K. D. \& Sutton, R. I. 1992. Acquiring organizational legitimacy through illegitimate actions: A marriage of institutional and impression management theories. Academy of Management Journal, 35: 699-738.

Farber, D. B. 2005. Restoring trust after fraud: Does corporate governance matter? The Accounting Review, 80: 539-561.

Farrell, K. A. \& Whidbee, D. A. 2002. Monitoring by the financial press and forced CEO turnover. Journal of Banking and Finance, 26: 2249-2276.

Fich, E. M. \& Shivdasani, A. 2005. Financial fraud, director reputation, and shareholder wealth. Unpublished, University of North Carolina. http://www.olin.wustl.edu/jfi/pdf/ financial.fraud.pdf (accessed April 17, 2006).

Fombrun, C. \& Shanley, M. 1990. What's in a name? Reputation building and corporate strategy. Academy of Management Journal, 33: 233-258.

Gerety, M. \& Lehn, K. 1997. The causes and consequences of accounting fraud. Managerial and Decision Economics, 18: 587599.

Hoskisson, R. E. \& Hitt, M. A. 1990. Antecedents and performance outcomes of diversification: a review and critique of theoretical perspectives. Journal of Management, 16: 461-509.

Hoskisson, R. E. \& Hitt, M. A. 1994. Downscoping: How to tame the diversified firm. New York: Oxford University Press.

$\mathrm{Hu}, \mathrm{H}$. C. 1944. The Chinese concept of "face". American anthropologist, 46(1): 45-64.

Jian, M. \& Wong, T. J. 2006. Propping and tunneling through related party transactions. Review of Accounting Studies, forthcoming.

Jiang, G. \& Wang, L. 2003. How far would management go to manage earnings? Working paper, Peking University.

Kam, A., Citron, D., \& Muradoglu, G. 2006. Restructuring strategies of Chinese firms in distress: Are they value enhancing? Cass Business School Research paper available at SSRN: http:// ssrn.com/abstract=910606 (accessed June 20, 2006).

Karpoff, J. M. \& Lott, J. R. 1993. The reputational penalty firms bear from committing criminal fraud. Journal of Law and Economics, 36: 757-802.

Khurana, I. \& Lippincott, B. 2000. Restructuring and firm value: The effects of profitability and restructuring purpose. Journal of Business, Finance and Accounting, 27: 1107-1130.

La Porta, R., Lopez-de-Silanes, L., \& Shleifer, A. 1999. Corporate ownership around the world. Journal of Finance, 54: 471517.

Liu, Q. \& Lu, Z. 2007. Corporate governance and earnings management in the Chinese listed companies: A tunneling perspective. Journal of Corporate Finance, forthcoming.

Livingston, J. G. 1997. Management-borne costs of fraudulent and misleading financial reports. Unpublished manuscript. Dallas: Southern Methodist University.

Maksimovic, V. \& Titman, S. 1991. Financial policy and reputation for product quality. Review of Financial Studies, 4: 175200.

Marcus, A. A. \& Goodman, R. S. 1991. Victims and shareholders: The dilemmas of presenting corporate policy during a crisis. Academy of Management Journal, 34: 281-305.

Markides, C. C. 1992. Consequences of corporate refocusing: Ex ante evidence. Academy of Management Journal, 35: 398412.

Meyer, A. D., Tsui, A. S., \& Hinings, C. R. 1993. Configurational approaches to organizational analysis. Academy of Management Journal, 36: 1175-1195.

Palmer, D., Barber, B., Zhou, X. G., \& Soysal, Y. 1995. The friendly and predatory acquisition of large U.S. corporations in the 1960s: The other contested terrain. American Sociological Review, 60: 469-499.

Palmrose, Z.-V., Richardson, V. J., \& Scholz, S. 2004. Determinants of market reactions to restatement announcements. Journal of Accounting and Economics, 37: 59-89.

Schlenker, B. R. 1980. Impression management: The self-concept, social identity, and interpersonal relations. Monterey, CA: Brooks/Cole.

Scott, W. R. 1977. Effectiveness of organizational effectiveness studies. In P. S. Goodman \& J. M. Pennings (Eds.), New perspectives on organizational effectiveness: 63-95. San Francisco: Jossey-Bass.

Scott, W. R. 1992. Organizations: Rational, natural and open systems (3rd ed.). Englewood Cliffs, NJ: Prentice Hall. 
Scott, W. R. 1995. Institutions and organizations. Thousand Oaks, CA: Sage.

Scott, W. R. \& Meyer J. W. 1991. The organization of societal sectors. In W. W., Powell \& P. J., DiMaggio (Eds.), The new institutionalism in organizational analysis: 108-140. Chicago: University of Chicago Press.

Staw, B. M., McKechnie, P. I., \& Puffer, S. M. 1983. The justification of organizational performance. Administrative Science Quarterly, 28: 582-600.

Stein, J. 1989. Efficient capital markets, inefficient firms: A model of myopic corporate behavior. Quarterly Journal of Economics, 104: 655-669.

Suchman, M. C. 1995. Managing legitimacy: strategic and institutional approaches. Academy of Management Review, 20: 571-610.

Tedeschi, J. T. 1981. Impression management theory and social psychological research. New York: Academic Press.

Wang, T. Y. 2004. Investment, shareholder monitoring and the economics of corporate securities fraud. Working paper, University of Maryland. http://www.usc.edu/schools/business/FBE/ FEA2004/FEApapers/J-SB_TYWANG-v3.pdf (accessed November 2004).

Wei, H. \& Fan, L. 2000. Empirical analysis on the Shanghai stock market efficiency. Forecast, 4: 10-24 (in Chinese).

Zahra, S. A., Priem, R. L., \& Rasheed, A. A. 2005. The antecedents and consequences of top management fraud. Journal of Management, 31: 803-828.

Zhang, Y. 2004. Law, corporate governance, and corporate scandal in an emerging economy: Insights from China. Available at SSRN: http:/ / ssrn.com/abstract=957549 (accessed November 2004).

Pengji Wang is a PhD candidate in the Department of Business Policy at the National University of Singapore Business School. Her research interests include institutional theory, corporate restructuring, corporate governance and $\mathrm{MNCs}^{\prime}$ foreign investment strategies in emerging economies. 